\title{
The Effect of Listening Strategy Instruction on Iranian Pre-intermediate EFL Learners' Listening Ability
}

Farzaneh Ghaed sharaf ${ }^{1}$, Melika Mobaraki², Maryam Rabani Nia ${ }^{3 *}$

${ }^{1}$ Velayat University, Iran

${ }^{2}$ University of Birjand, Iran

${ }^{3}$ Chabahar Maritime University, Iran

Corresponding Author: Maryam Rabani Nia, E-mail: Rabani.maryam@yahoo.com

\section{ARTICLE INFO}

Article history

Received: December 01, 2017

Accepted: February 06, 2018

Published: May 01, 2018

Volume: 7 Issue: 3

Advance access: March 2018

Conflicts of interest: None

Funding: None

\begin{abstract}
Listening comprehension plays an important role in the process of language learning as it is one of the four major skills in language acquisition. This study was conducted to investigate the effectiveness of listening strategy instruction on improving listening comprehension of Iranian EFL learners. To achieve this goal, forty students studying at Birjand University were participated in the current study. All of thestudents were within the age range of 18 to 22 . Then, they were non-randomly divided into two groups, as a control and an experimental group. Theexperimental was taught based on a guide lesson plan regarding listening strategies while the control group did not receive any treatment. The listening section of TOEFL was utilized to measure the listening performance of the participants before and after the treatment. The results of Independent Samples Test indicated thatinstructing listening strategies had no significant impact onlistening comprehension of Iranian pre-intermediate EFL learners.
\end{abstract}

Key words: Listening Ability, Strategy Instruction, Listening Comprehension, EFL Learners, Cognitive Strategies

\section{INTRODUCTION}

Listening has an important role in communication, so that 40 $50 \%$ of the total time spent on communication is allocated to listening (Mendelsohn, 1994). Understanding and comprehending spoken language is fundamentally an inferential process (Rost, 2011). Listeners apply both linguistic knowledge and world knowledge to create a mental representation of what they have heard (Hulstijn, 2003). Long ago, Listening Comprehension (LC) has been considered as a passive activity and researchers did not pay attention to this skill (Birjandi, 2012). It had been assumed that a learner's ability to comprehend spoken language would develop entirely on its own through repetition and imitation. The focus of earlier LC materials was primarily on testing students' ability to listen to oral discourse and then answer the comprehension questions based upon the incoming information (Carrier, 2003; Field, 1998). As Chastain (1971) mentions, the aim of LC is to understand the native conversation at normal rate in a spontaneous condition. So, according to Nunan (1998), in language learning, the basic skill is listening.Unlike listening in First Language (L1) condition which is a natural, implicit process and learners use many strategies automatically to help them fully comprehend the message, in a Second Language (L2) setting, it is even more important to use these helpful strategies to decode the message. As most of the L2 learners are not aware of L1 strategies in order to transfer them in L2 situation, it is necessary to train L2 learners to call upon and use these strategies that help them to comprehend better. So through Strategy Instruction (SI), the learners' awareness of useful strategies can be raised, at the very least, and in practicing strategies in a controlled, comfortable classroom setting, learners will see their capabilities when using these strategies and breakdown the helpless feeling that can often come when listening in an L2 (Mendelsohn, 1994).

\section{REVIEW OF RELATED LITERATURE}

One important method that helps ESL/EFL learners to control their learning is using strategies. Vandergrift (1999) showed that "strategy development is important for listening training because strategies are conscious means by which learners can guide and evaluate their own comprehension and responses". So, Listening Comprehension Strategy (LCS) can be defined as "a sequence of steps (mental or behavioral) taken deliberately by listeners (always conscious) in a specific order (depending on the task complexity), to enhance the ability to perceive, and internalize as well as comprehend the listening input" (El Sayed, 2002). Most of the previous researches on L2/FL listening refer to three types of strategies to overcome difficulties with LC: cognitive, metacognitive and socio-affective strategies. 


\section{Cognitive Strategies in Listening Comprehension}

"Cognitive strategies are mental activities related to comprehending and storing input in working memory or longterm memory for later retrieval" (Buck, 2001, p. 104). These type of strategies are behaviors, techniques or actions used by learners in order to facilitate acquisition of knowledge or skill (Ratebi, 2013). This strategy is a problem-solving technique used by the learners to deal with the learning task and the acquisition of knowledge becomes easier for them (AzmiBingol, 2014). Language learners use this kind of strategy as a help for processing, storing and recalling new information (Goh, 1998). There exist different types of cognitive strategies: cognitive formal practicing strategy (previewing, resourcing, note taking, remarking the key ideas), cognitive translation, cognitive bottom-up strategies (deduction, repetition, segmentation, transfer), cognitive top-down strategies (listening for the main ideas, inferencing, thinking in English, elaborating) but bottom-up and top-down strategies are the most popular strategies between researchers for more investigation.

\section{Metacognitive Strategies in Listening Comprehension}

According to Rubin (1987), metacognitive strategies are management techniques that learners use to control their learning through planning, monitoring, evaluating, and modifying (cited in Abdalhamid, 2012). Based on the definition of metacognitive strategies by scholars, ThanhHuy (2015) divided metacognitive strategies into three sets: concerning learning (paying attention), arranging and planning learning, and evaluating it. Using metacognitive strategies consciously, gives the opportunity to learners to get back their focus when they lost it (Oxford, 1990). There exist two types of metacognitive ability: knowledge of cognition related to learners' awareness of what is going on (i.e., knowing what) and the other is regulation of cognition (i.e., knowing how) which concerned with what learners should do to listen effectively (Baker \& Brown, 1980).

\section{Socio-Affective Strategies in Listening Comprehension}

The last category of strategies is socio-affective, which is defined by Vandergrift (2003) as the techniques listeners use to collaborate with others, to verify understanding, or to lower anxiety. Gardner and MacIntyre (2013) maintained the important role of effective strategies which is employed to control learning experiences, because it is directly related to learning context and learners' social-psychological factors. Ratebi (2013) believes that socio-affective strategies are a collection of strategies for controlling resource, time, effort and support.

Over the past three decades, several studies manage to show that learners can gain benefits from use of strategies for developing their listening comprehension (Underwood, 1989; Willing, 1989; Mendelsohn, 1994; Thompson and Rubin, 1996; Vandergrift, 1997). These studies searched the importance of listening strategy instruction with focus on various features, including teaching students to become strategically smart, enabling them to develop meta-strategic awareness, teaching them to plan for the successful completion of a listening task, teaching them how to monitor their comprehension during a listening task along with the teaching of evaluation processes and the use of checklist for learners' development. Thompson and Rubin's (1996) study was a thorough work which analyzed a large number of listening strategy studies in order to answer the prime question that "can strategy instruction improve listening comprehension?" in general.

In this consideration, several works in our Iranian EFL context also probed the importance of the use of listening strategies, and the way its instruction can be seen in connection with other features in language development. As an instance, Rasouli, Mollakhan, and Karbalaei (2013) studied the effect of metacognitive listening strategy training on listening comprehension in Iranian EFL context. They concluded that the result of their pretest and posttest standardized measure of listening comprehension and metacognitive listening strategy questionnaire demonstrated that learners benefited from listening strategy instructions. Other studies were also examined features like motivation development by the use of listening strategies, individual differencesin using listening strategies, the university learners' language proficiency levels in connection with their ability of the use of listening strategies, the role of listening strategy on the anxiety of Iranian IELTS learners, etc. (Baleghizadeh and Rahimi, 2011; Serri, Jafarpour and Hesabi, 2012; Shirani and Yamat, 2011, Mohammadi, 2012).

However there seems not to be a conclusive study in our Iranian EFL context to demonstrate that the instruction of listening strategies should be comprehensive and mere representation of one or two strategies cannot show the actual influence ofinstruction. So the present study conducted to answer the following research question:

Q: Does the instruction of listening strategies have any significant impact on improving listening comprehension of Iranian pre-intermediate EFL learners?

\section{METHODOLOGY}

\section{Participants}

The population of this study is comprised of 40 homogenized freshman students, majoring in English Translation and Literature at Birjand University, in South Khorasan Province, Iran, having listening course. All the participants were learning English as L2 language and were native speakers of Persian. They were betweenthe ages of 18 and 22 years old and were selected based on a non-random purposive sampling technique because of the convenience and the availability of the sample. They were divided into two groups, experimental and control, with 20 mixed-gender ones in each.

\section{Instrumentation}

The instruments used in this study consisted of a TOEFL practice listening test. This test was used as a pre-test and post-test in order to specify the proficiency level of EFL 
learners and also to indicate the effectiveness of the treatment. The second instrument wasaguidelesson plan of LS that included a clear definition of each strategy, sub-categories of each strategy and the time that can use them.

\section{Procedure}

In order to answer research question, two groups (mixed gender) were selected to explore the improvement of Iranian EFL learners in listening comprehension. The data collected during eight weeks having two sessions a week.Both groups of the participants (experimental and control group) were firstly required to take TOEFL listening test. After the pretest. The researcher taught four sessions of LS to the class. First session devoted to Metacognitive Strategies. The second devoted to Cognitive Strategies. The third session dealt with instruction of Socio-affective Strategies. After these four sessions, learners continued their listening course without any manipulation, consideration, and treatment. After a ten session interval, learners have been given a parallel language listening test of TOEFL as their post-test (both groups).

\section{RESULTS}

Tables 1 and 2 show the descriptive and inferential statistics of the two groups' scores on listening pre-test.
As the results of Table 1 illustrate, the mean of the scores of control group is higher than the mean of the scores of experimental group. According to Table 2, since the $\mathrm{p}$ value (sig.) equals 0.265 and it is higher than the critical value (0.05), the equal variance assumed is accepted, and since the level of significance in the equal variances assumed equals 0.942 and it is higher than critical value $(0.05)$, the equal variances assumed is not rejected. It means that there is no significant difference between the pre-test scores of the two groups. After the treatment, a listening post-test was given to the groups in order to investigate whether the treatment had a significant impact on the participants' LC. Tables 3 and 4 indicate the descriptive and inferential statistics and Independent Samples Test results.

The results of this tables illustrate that the mean of the scores for the control group is higher than that of the experimental group (based on Table 3: 15.18>15.15). Additionally, as Table 4 demonstrates, the $\mathrm{p}$ value (sig.) equals 0.122 and is higher than the critical value (0.05), so the assumption of equal variances is accepted. As the level of significance equals 0.780 and it is higher than the critical value (0.05), the assuming average equality is not rejected. Therefore, it can be concluded that the treatment had no significant impact on participants' listening performance of the experimental group.

Table 1. Descriptive statistics of the control and cxperimental groups for listening Pre-test

\begin{tabular}{lllccc}
\hline & Grouping. variable & N & Mean & Standard deviation & Standard error mean \\
\hline Pre-test.score & Exp.group & 20 & 14.4500 & 5.90695 & 1.32084 \\
& Cont.group & 20 & 14.6000 & 6.98419 & 1.56171 \\
\hline
\end{tabular}

Table 2. Independent samples test results of listening pre-test between the control and experimental groups

\begin{tabular}{|c|c|c|c|c|c|}
\hline & \multicolumn{2}{|c|}{ Levene's test for equality of variances } & \multicolumn{3}{|c|}{ T-test for equality of means } \\
\hline & $\mathbf{F}$ & Sig. & $\mathbf{t}$ & df & Sig. (2-tailed) \\
\hline \multicolumn{6}{|l|}{ Pre-test. score } \\
\hline $\begin{array}{l}\text { Equal variances assumed } \\
\text { Variances }\end{array}$ & 1.282 & 0265 & -0.073 & 38 & 0.942 \\
\hline $\begin{array}{l}\text { Equal variances not } \\
\text { assumed }\end{array}$ & & & -0.073 & 36.981 & 0.942 \\
\hline
\end{tabular}

Table 3. Descriptive statistics of the control and experimental groups for listening post-test

\begin{tabular}{lllccc}
\hline & Grouping. variable & N & Mean & Standard deviation & Standard error mean \\
Post-test.score & Exp.group & 20 & 15.1500 & 6.31018 & 1.41100 \\
& Cont.group & 20 & 15.8000 & 8.17313 & 1.82757 \\
\hline
\end{tabular}

Table 4. Independent samples test results of listening post-test between the control and experimental groups

\begin{tabular}{|c|c|c|c|c|c|}
\hline & \multicolumn{2}{|c|}{ Levene's test for equality of variances } & \multicolumn{3}{|c|}{ T-test for equality of means } \\
\hline & $\mathbf{F}$ & Sig. & $\mathbf{t}$ & df & Sig. (2-tailed) \\
\hline \multicolumn{6}{|l|}{ Post-test.score } \\
\hline Equal variances assumed & 2.497 & 0.22 & -0.282 & 38 & 0.780 \\
\hline Equal variances not ass & & & -0.282 & 35.713 & 0.780 \\
\hline
\end{tabular}




\section{DISCUSSION}

The results showed that LSI did not improve the listening comprehension of Iranian pre-intermediate EFL learners. The results obtained from the present study, as far as the relationship between LSI and LC is concerned, is in line with a few studies in the past. In an earlier study conducted by Ridgway (2000), he argued that LSI was a waste of time. His reason for this claim was that learners do not have the cognitive capacity to consciously active taught strategies and listen simultaneously, and isolating individual LS for explicit instruction and determining if they are being utilized by listener is unrealistic. He also believed that as the listening is the engagement of the listener and the text, when this engagement was completed no cognitive capacity will remain for operating conscious strategies. In another study, Cross (2009) investigated the effect of LSI on LC of Japanese EFL learners. An experimental group received 12 hours of LSI while a control group did not receive any explicit SI. Results indicated a significant improvement for both groups and they had better performance according to the results of post-test. He concluded that this promotion was not due to the treatment and no relationship was between LSI and LC performance. These findings were in contrast with previous findings obtained from studies conducted by Chen (2015), Gebre and Tadesse (2015), Zhang (2012) and other researchers. The final results of their studies indicated that strategies-based instruction played a positive role in determining students' improvement in LC.

There are also some studies in Iranian EFL context that are in contrast with the findings of this research but are not as comprehensive as this study. For example, Bagheri and Karimi (2014) investigated the effect of explicit teaching of LS and gender on EFL learners' IELTS performance. The findings clarified that LSI could improve participants' listening score. Hosseini (2013) conducted a research to find the effect of LSI on documentary video comprehension. The results revealed that teaching LCS had significance effect on comprehension of authentic documentary videos. The similar results were obtained by Moradi (2012), and Sobouti and Amiri(2014). Other studies investigated the relationship between one of those strategies and listening achievement in Iranian context that have contrasted results with the present study. For example, investigating the effect of metacognitive strategies were conducted by Hariri (2014), Rahimirad (2014), Rasouli, Mollakhan and Karbalaee (2013) and many others who mentioned the effectiveness of metacognitive SI. There are just a few studies in Iranian context which found the positive relationship between cognitive strategies and listening performance such as Mir Ghaemi (2011); and Firoozjahantigh and Ghahraman (2016). The results of these studies were reflective of the efficacy of the treatment applied to the experimental groups.

\section{CONCLUSION}

The current study proposes that listening strategy instruction (metacognitive, cognitive and socio-affective strategies) does not result in the improvement of EFL learners' LC. As the result of Independent Samples Test showed, there was not a significant difference between the control and experimental group based on final TOEFL listening scores. Perhapsthe ineffectiveness of this research was due to teaching of all these three listening strategies (metacognitive, cognitive and socio-affective strategies) at the same time. This matter caused participants to confuse and could not distinguishwhich strategy they should use related to different LC questions and situations. Another reason for ineffectiveness of this study is the limitation of time. If more time spent for teaching these three strategies, maybe the result was different.

\section{REFERENCES}

Abdalhamid, F. (2012). Listening Comprehension Strategies of Arabic-Speaking ESL Learners (M.A dissertation). Colorado State University: Fort Collin, Colorado.

AzmiBingol, M. (2014). Listening Comprehension Difficulties Encountered by Students in Second Language Learning Class. Journal of Educational and Instructional Studies in the World, 4(4).

Bagheri, M., \&Karimi, S. (2014). The Effect of Explicit Teaching of Listening Strategies and Gender on EFL Learners' IELTS Performance. Journal of Language and Research, 5(6), 1387-1392.

Baker, L. \& Brown, A.L. (1980). Metacognitive Skills and Reading. Handbook of Reading Research.

Baleghizadeh, S., \&Rahimi, A. H. (2011). The Relationship among Listening Performance, Metacognitive Strategy Use and Motivation from a Self-determination Theory Perspective. Theory and Practice in Language Studies, 61-67.

Birjandi, P. (2012). The Effect of Metacognitive Strategy Instruction on the Listening Performance of EFL Students. International Journal of Linguistics, 4(2).

Buck, G. (2001). Assessing Listening. New York: Cambridge University Press.

Carrier, K. A. (2003). Improving High School English Language Learners' Second Language Listening through Strategy Instruction. Bilingual Research Journal, 27(3), 383-408.

Chastain, K. (1971). Affective and Ability Factors in Second Language Acquisition. Language Learning, 25(1).

Chen, A. (2010). Effects of Listening Strategy Training for EFL Adult Listeners. The Journal of Asia TEFL, 7(1), 135-169.

Cross, J. (2009). Effects of Listening Strategy Instruction on News Videotext Comprehension Language. Language Teaching Research, 13(151). DOI: $10.1177 / 1362168809103446$.

Field, J. (1998). Skills and Strategies: Towards a new Methodology for Listening. Retrieved from: http://eltj.oxfordjournals.org.

Firoozjahantigh, M., \&Ghahraman, V. (2016). Explicit Instruction of Cognitive Strategies: The case of Iranian EFL Learners' Listening Achievement. International Journal of Language Learning and Applied Linguistics World, 11(3), 1-21. 
Gardner, R. C., \&MacIntyre, P. D. (2013). A Student Contribution to Second Language Learning. Part I: Cognitive Variable. Language Teaching, 25(4), 211-220.

Gebre, B. M., \&Tadesse, G. G. (2015). The Role of Listening Strategy Instruction in Advancing Students' Listening Achievement and Strategy Use. International Journal of Foreign Language Teaching and Research, 3(11).

Goh, C. C. (1998). How ESL Learners with Different Listening Abilities Use Comprehension Strategies and Tactics. Language Teaching Research, 2, 124-1147. Doi: $10.1177 / 136216889800200203$.

Hariri, M. (2014). The Effect of Meta-Cognitive Strategies Instruction on Listening Comprehension of Iranian Pre-Intermediate Female EFL Learners. International Journal of Social Science and Education, 4(2), 437-441.

Holden, W.R. (2004). Facilitating Listening Comprehension: Acquiring Successful Strategies. Bullentin of Hokiruku University, 28, 257-266.

Hosseini, F. (2013). Teach How to Listen: The Effect of Listening Strategy Instruction on Documentary Video Comprehension. International Letters of Social and $\mathrm{Hu}$ manistic Sciences, 9, 11-21.

Hulstijn, J. H. (2003). Connectionist Models of Language Processing and the Training of Listening Skills with the Aid of Multimedia Software. Computer Assisted Language Learning, 16(5), 413-425.

Mendelsohn, D. (1994). Learning to Listen: A Strategy-based Approach for the Second-Language Learners. San Dieg, CA: Dominie.

Mir Ghaemi, S. M. (2011). The Effect of Instructing Cognitive Listening Strategies on Test-taking Anxiety and Test Performance of Iranian EFL Learners (M.A dissertation). AllamehTabataba'i University.

MohammadiGolchi, M. (2012). Listening Anxiety and Its Relationship with listening Strategy Use and Listening Comprehension among Iranian IELTS Learners. International Journal of English Linguistics, 2(4)

Moradi, Kh. (2012). The Impact of Listening Strategy Instruction on Academic Lecture Comprehension: A Case of Iranian EFL Learners. Procedia-Social and Behavioral Sciences (70), 406-416. Doi:10.1016/j.sbspro.2013.01.078.

Nunan, D. (1998). Approaches to Teaching Listening in Language Classroom. In proceedings of the 1997 Korea TESOL Conference. Taejon, Korea: KOTESOL.

Oxford, R.L. (1990). Language Learning Strategies: What Every Teacher Should Know. New York: Newbury House.

Oxford, R. L. (2003). Language Learning Styles and Strategies: An Overview. Learning Styles and Strategies, 3, 53-66.

Rahimirad, M. (2014). The Impact of Metacognitive Strategy Instruction on the Listening Performance of Univer- sity Students.Procedia- Social and Behavioral Sciences, 98, 1485-1491.

Rasouli, M., Mollakhan, K., \&Karbalaei, A. (2013). The Effect of Metacognitive Listening Strategy Training on Listening Comprehension in Iranian EFL context. European Online Journal of Natural and Social Sciences, 2(1), 115-128.

Ratebi, Z. (2013). Use of Metacognitive Strategies in Listening Comprehension by Iranian University Students Majoring in English: A Comparison between High and Low Proficient Listeners. Journal of Studies in Education, 3(1).

Ridgway, T. (2000). Listening Strategies: I Beg Your Pardon? ELT Journal, 54(2), 179-185.

Rost, M. (2011). Teaching and Researching Listening.Pearson Educational Limited.

Serri, F., JafarpourBroujeni, A., \&Hesabi, A. (2012). Cognitive, Metacognitive and Social/Affective Strategies in Listening Comprehension and their Relationship with Individual Differences. Theory and Practice in Language Studies, 2(2), 843-849.

Shirani, F., Yamat, H. (2011). The Relationship between Listening Strategies used by Iranian EFL Freshman University Students and their Listening Proficiency Level. English Language Teaching, 26-32.

Sobouti, F., \&Amiri, M. (2014). The Impact of Listening Strategy Instruction on the Improvement of Iranian Intermediate EFL Learners' Comprehension of News Videotexts. Academic Research International, 5(2).

ThanhHuy, L. H. (2015). An Investigation into Listening Strategies of EFL Students within the High School Setting. Asian Journal of Educational Research, 3(4).

Thompson, I., \& Rubin, J. (1996). Can strategy instruction improve listening comprehension? Foreign Language Annals, 331-342.

Underwood, M. (1989). Teaching Listening. London: Longman.

Vandergrift, L. (1997). The Cinderella of communication strategies: Reception strategies in interactive listening. Modern Language Journal, 81-84.

Vandergrift, L. (1999). Facilitating Second Language Listening Comprehension: Acquiring Successful Strategies. ELT journal, 53(3), 387-409.

Vandergrift, L. (2003). Orchestrating Strategy Use: Toward a Model of the Skilled Second Language Listener. Language Learning, 463-496.

Willing, K. (1989). Teaching how to learn: A teacher's guide. Sydney, Australia: Macquarie University, NCELTR.

Zhang, Y. (2012). The Impact of Listening Strategy on Listening Comprehension. Theory and Practice in Language Studies, 2(3), 625-629. DOI: 10.4304/ tpls.2.3.625-629. 